\title{
Manure application timing drives energy absorption for snowmelt on an agricultural soil
}

\section{Melanie N. Stock ${ }^{a *}$, Francisco J. Arriaga ${ }^{b}$, Peter A. Vadas ${ }^{\text {, }}$, and K.G. Karthikeyan ${ }^{\text {d }}$}

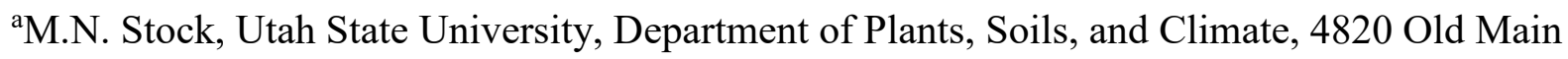
Hill, Logan, UT 84321, USA; melanie.stock@usu.edu

${ }^{b}$ F.J. Arriaga, University of Wisconsin-Madison, Department of Soil Science, 1525 Observatory Drive Madison, WI 53706, USA; farriaga@wisc.edu

'P.A. Vadas, USDA-ARS, U.S. Dairy Forage Research Center, 1925 Linden Dr., Madison, WI 53706, USA; Peter.Vadas@ARS.USDA.GOV

${ }^{\mathrm{d}}$ K.G. Karthikeyan, University of Wisconsin-Madison, Department of Biological Systems Engineering, 460 Henry Mall, Madison, WI 53706, USA; kkarthikeyan@wisc.edu

*Corresponding author: Melanie N. Stock 


\begin{abstract}
Reducing agricultural runoff year-round is important, in particular during snowmelt events on landscapes that receive wintertime applications of manure. To help inform manure guidelines, process-level data are needed that link management scenarios with the complexity of snowmelt, hence runoff. Albedo and radiative energy fluxes are strong drivers of thaw, but applying these mechanistic measurements across multiple, plot-scale management treatments over time presents a logistical challenge. The objective of this study was to first develop a practical field approach to estimate winter albedo in plot-scale field research with multiple management scenarios. The second objective was to quantify the radiative drivers of snowmelt by measuring fluxes after wintertime liquid manure application. Six management treatments were tested in south-central Wisconsin during the winters of 2015-2016 and 2016-2017 with a complete factorial design: three manure application timings (early December, late January, and unmanured) and two tillage treatments (conventional tillage versus no-tillage). A multiple linear regression model was developed to estimate albedo with digital imagery and readily-obtained site characteristics. Manure timing had a significant effect on radiative energy fluxes and tillage was secondary. January applications of liquid manure produced an immediate and lasting decrease in albedo, which resulted in greater net radiation absorbed by snowpack and subsequent energy available for snowmelt. Later applications of liquid manure accelerated snowmelt, which increased runoff losses and posed a challenge for nutrient retention from the liquid manure during thaw.
\end{abstract}

Keywords: agriculture; manure; tillage; albedo; frozen soil; snow energy balance 


\section{Introduction}

Nutrient loading from agricultural runoff is the leading cause of nonpoint source surface water impairment (Carpenter et al., 1998; USEPA, 2015) and in temperate climates, most annual runoff occurs on frozen soils (Good et al., 2012). With greater risk of runoff, effective management is particularly important for wintertime land-applications of manure, a longstanding and essential disposal practice for many dairy producers (Srinivasan et al., 2006). As the sensitive winter season motivates revisions to manure application policy and recommendations (e.g. WI Nutrient Management Standard 590, USDA NRCS, 2015), a need exists for more conclusive data regarding winter runoff processes relative to management decisions (Srinivasan et al., 2006). Most agriculture research has been conducted prior to 1980 with limited replication, and focused on runoff from solid-bedded dairy manures (13.8-55.5\% dry matter, DM) applied at different times during the winter (Hensler et al., 1970; Converse et al., 1976; Klausner et al., 1976; Young and Mutchler, 1976). Year-to-year trends were inconsistent, but overall, early-winter applications of manure on bare soil tended to increase runoff compared to late-winter applications on top of snowpack, and unmanured controls produced the highest runoff volumes (Hensler et al., 1970; Converse et al., 1976; Young and Mutchler, 1976). The results were attributed to the general complexity of weather and snowmelt, as mechanistic data relating the manure practices to winter runoff processes were lacking.

Kongoli and Bland (2002) determined the drivers of these runoff trends by measuring energy for snowmelt relative to solid-bedded manure (40-50\% DM) applied on top of snow and unmanured controls. As the presence of manure decreased the snow surface albedo from 0.85 to 0.11 , the absorption of solar radiation increased. In turn, the radiant surface temperature of the manure layer rose above freezing and up to seven degrees Celsius higher than that of the snowpack 
in the unmanured control. Because of the low thermal conductivity of the solid-bedded manure (range: $0.08-0.20 \mathrm{~W} \mathrm{~m}^{-1} \mathrm{~K}^{-1}$ ), however, the absorbed energy was confined to the surface of the manure layer and the underlying snowpack was insulated during thaw events. Retarding snowmelt through applications on top of snowpack presumably reduced runoff and nutrient losses by increasing the amount of time for infiltration, relative to early applications on bare frozen soil, though runoff and infiltration were not measured.

The mulching effect of solid-bedded manure, which was the predominant form of manure generated at the time, may not be applicable to liquid manure $(<11 \% \mathrm{DM})$, which is now much more common (USDA-NASS, 2010). In a comparison of winter-applied liquid swine manure (4 $\% \mathrm{DM})$ to turkey litter (57 \% DM), overall runoff loads were greater from the liquid manure, despite the higher nutrient load within the turkey litter at application (Owens et al., 2011). Other comparisons, such as wintertime applications of liquid dairy manure to no-tillage and disk-tillage fields, were also mixed and cited challenges from limited replication of treatments and complex weather and field conditions (Komiskey et al., 2011). Few studies have evaluated the winter management of liquid manure applications, but recent research that evaluated runoff outcomes provided insight into the current practices of most producers. The emphasis for a mechanistic approach to determine environmental conditions that are appropriate for winter spreading remains.

The high water content of liquid manure likely interacts differently with snowpack than solidbedded manure. For example, liquid manure may have a greater thermal conductivity and tendency to distribute within snowpack instead of maintaining a thick, discrete layer (Vadas et al., 2017). Applications of liquid manure on top of snowpack may then accelerate melt by lowering the snow surface albedo and transmitting absorbed energy directly to melt processes. Even small amounts of impurities, such as soot, significantly reduce snow surface albedo (Warren and Wiscombe, 
1985). Because radiative fluxes dominate the rate of snowmelt in open systems with relatively shallow snowpack (Gray and Landine, 1987), increases in absorbed solar radiation from liquid manure may significantly impact snowmelt dynamics.

The overall goal of this work was to understand the effect of liquid dairy manure specific to the radiative processes that drive snowmelt in order to mechanistically identify management practices that may reduce - or accelerate - wintertime losses. The need for replication of management treatments, paired with the need for repeated physical measurements of albedo and radiative fluxes, however, requires numerous net radiometers and this is often cost prohibitive. The option of moving a few sensors frequently between plots is often impractical due to their fragility and the extreme winter environment. Satellite data (e.g. MODIS, Landsat) are also inappropriate for plot-scale studies. Most of the energy reflected by snowpack is within the visible band of the electromagnetic spectrum, making digital imagery a strong option for plot-scale estimates of albedo (Corripio, 2004). Consequently, the first objective developed a cost-effective and practical field approach to measure albedo within the visible wavelengths for plot-scale research with digital imagery and measured snow parameters. The second objective was to quantify the radiative fluxes from liquid dairy manure and snowpack using a plot-scale approach that allowed for replication of both management treatments and physical measurements of the radiative energy balance.

\section{Materials and methods}

\subsection{Site description and treatments}

The field study was conducted at the University of Wisconsin - Madison Arlington Agricultural Research Station (AARS; $43^{\circ} 17^{\prime} \mathrm{N} 89^{\circ} 21^{\prime} \mathrm{W}$ ) as part of a larger investigation of winter surface nutrient transport in dairy agroecosystems. A total of 18 plots $(5 \times 15 \mathrm{~m}$ each) were 
established on a south-facing, $5.8 \%$ sloped field that was cropped with continuous corn for silage. Corn was planted along the contour in each plot with a 76-cm row spacing. Soil in the research area was a Saybrook-Ringwood-Griswald series association with a silt-loam texture. These soils were formed from loess material with underlying glacial till. Soil organic matter content was 4.0 $\%$ (standard error, $\mathrm{SE}=0.04$ ) at a $0-2.5 \mathrm{~cm}$ depth.

Two tillage and three manure treatments in a full factorial design were established in triplicate for two winter seasons (2015-2016 and 2016-2017) to test the snowmelt dynamics and hydrology of frozen soils under common management practices. Tillage treatments were conventional tillage (CT) with a fall chisel plow and spring finisher on the contour and no-tillage (NT), which resulted in rough and smooth soil surfaces, respectively. The typical timing of winter manure applications was represented with three manure treatments: an early-December application at the typical onset of the freezing season (D), a late-January application midway through the freezing season (J), and an unmanured control (C). Liquid dairy manure (DM 2-6\%) was supplied from the Emmons Blaine Dairy Facility at AARS and applied manually at a rate of $37.4 \mathrm{~kL} \mathrm{ha}^{-1}$, which contained approximately $87 \mathrm{~kg} \mathrm{ha}^{-1}$ of total nitrogen and $13 \mathrm{~kg} \mathrm{ha}^{-1}$ of total phosphorus. The application dates included: 10 Dec. 2015, 26 Jan. 2016, 09 Dec. 2016, and 27 Jan. 2017. All field operations were performed along the contour (i.e. tillage, harvest, and manure application). Six to 12 manure samples were collected during each application and the percent of dry matter was measured by drying. The thermal conductivity of the manure was tested with a thermal property analyzer (KD2 Pro, Decagon Devices, Inc., Pullman, WA). Manure nutrients were analyzed by the University of Wisconsin Soil and Forage Analysis Laboratory (Marshfield, WI, USA), where total nitrogen was measured by using methods of Peters et al. (2003), Section 3.2, and phosphorus concentrations were measured with colorimetric spectrophotometry after dry ashing (Section 5.2). 


\subsection{Field measurements}

Atmospheric, soil, and hydrologic parameters were measured using automated and manual instruments to target the radiative energy balance, relative to manure applications and tillage. An on-site weather station was equipped with an air temperature and vapor pressure sensor (VP-3, Decagon Devices Inc., Pullman WA) and a tipping-bucket rain gauge (RG3, Onset Computer Corporation, Bourne, MA) modified to measure snowfall as the liquid equivalent (CS705, Campbell Scientific, Inc., Logan, UT). The weather station scanned every minute and stored hourly averages of air temperature $\left({ }^{\circ} \mathrm{C}\right)$, vapor pressure $(\mathrm{kPa})$, and the total hourly precipitation (mm) with a datalogger (model CR1000, Campbell Scientific, Inc., Logan, UT). Soil frost was monitored with a frost tube installed in each plot (Rickard \& Brown, 1972; MacKay, 1973). Three snow sticks were installed in each plot equidistantly along the slope for the manual measurement of snowpack depth to the nearest $\mathrm{mm}$. The snow-water equivalent (SWE), defined as the height of water stored as snow in $\mathrm{mm}$, was calculated by measuring the density of the snow $\left(\mathrm{g} \mathrm{cm}^{-3}\right)$ in each plot with a snow corer (U.S. Army Corps of Engineers, 2015). These measurements of frost and snow were collected at least once every week, and up to daily during precipitation and thaw events.

Runoff was monitored with a storm-integrated, discharge-weighted collection system for each plot (Bonilla et al., 2006; Vadas and Powell, 2013). The area of each plot $\left(75 \mathrm{~m}^{2}\right)$ was hydrologically isolated with earthen berms. Runoff was directed into a passive, divider collection system that consisted of three, sequential $19 \mathrm{~L}$ buckets for each plot. The first two buckets of each system were topped with a steel crown that had 24 precision-cut, $\mathrm{V}$-slot weirs that directed $1 / 24^{\text {th }}$ of the runoff water to the subsequent bucket, allowing for up to a $11.4 \mathrm{~kL}(152 \mathrm{~mm})$ event to be captured. After each runoff event, the height of the water in each bucket was measured with a meter stick to the nearest $\mathrm{mm}$. To determine nutrient loads for each plot, a water sample was also collected for each bucket. The dilution ratio from the weirs was then used to calculate the total runoff volume and nutrient loads of the event 
for each plot. Water samples were stored at $4^{\circ} \mathrm{C}$ until analysis. Unfiltered samples were colorimetrically analyzed for total Kjeldahl nitrogen (TKN) and total Kjeldahl phosphorus (TKP) after digestion (AQ2 Discrete Analyzer, SEAL Analytical Brand, Mequon, WI; Seal, 2017). Filtered samples $(0.45 \mu \mathrm{m})$ were analyzed for dissolved reactive phosphorus (DRP; Murphy and Riley, 1962), and nitrate-N $\left(\mathrm{NO}_{3}{ }^{-}-\mathrm{N}\right)$ with a Lachat automated analyzer (Wendt, 2000). Total Nitrogen (TN) was calculated as the sum of TKN and $\mathrm{NO}_{3}{ }^{-} \mathrm{N}$. Nutrient loads were calculated by multiplying the nutrient concentrations by the runoff volume for each plot.

One replicate per treatment (i.e. six plots) was equipped with additional instrumentation. An infrared radiometer (SI-111, Apogee Instruments, Logan, UT) measured the ground surface temperature (soil or snow, when present). The infrared radiometers were mounted at a height of $1.2 \mathrm{~m}$ above the soil surface to measure temperature every minute, and hourly averages were recorded with dataloggers (model CR1000, Campbell Scientific, Inc., Logan, UT). During the freezing season of 2015-2016, one net radiometer (NR01, HuksefluxUSA, Center Moriches, NY) was mounted at a $30 \mathrm{~cm}$ height above the soil surface and rotated between the six plots. During the freezing season of 2016-2017, three net radiometers were rotated between plots. Hourly averages of incoming and reflected solar radiation and longwave radiation, surface temperature, and albedo were recorded with dataloggers (model CR10X, Campbell Scientific, Inc., Logan, UT).

\subsection{Albedo Estimation}

By February 2016, there was a clear need to frequently estimate albedo in each of the plots and a net radiometer proved inadequate. As such, a multiple linear regression (MLR) model of digital imagery, surface and weather conditions, and known albedo values (measured by the net radiometers) was developed for 40 dates during the 08 February to 14 March 2016, and 5 December 2016 to 21 March 2017 winter periods. Snow was present during all the dates included in the model and ranged from discrete patches and thin dustings of new snowfall $(<1 \mathrm{~mm}$ depth, 
below the measureable limit) to thick, continuous snowpack layers with or without the presence of manure. Bare soil was not intended to be represented by this model. Dates in which the soil had no snow cover were represented with net radiometer data and were not included in the MLR, as albedo becomes nonlinear and is a well-established function of soil moisture content at values less than 0.1 (Idso et al., 1975; Lobell \& Asner, 2002).

Using a $1 \times 1 \mathrm{~m}$ quadrat, one representative and undisturbed area within each plot was selected at random on each date. A digital image of the quadrat was photographed with a cellphone camera (Samsung Galaxy S5, Samsung Electronics Co., Ltd., Suwon, South Korea), in which all automatic settings were turned off [i.e. flash, high dynamic range (HDR), low light detection, and selective focus] and the ISO was set to 800 . For plots with net radiometers, the quadrat was placed directly beneath the net radiometer and a second image was photographed for that plot. Images were photographed between 10:00-14:00 local time. A reflectance plate (Spectralon Targets \#SRT-99120, Labspere, Inc., North Sutton, NH) was used to verify even pixel distribution. All images were processed with open-source ImageJ software using the Fiji image processing package (Schindelin et al., 2012). Each image was corrected for distortions with Interactive Perspective, cropped to $2.25 \mathrm{M}$ pixels (1500 x 1500 pixels) within the quadrat, and an RGB Histogram of the 8-bit (0255) pixel values was plotted, with 0 representing black and 255 representing white ends of the color spectrum. The pixel mean, standard deviation, minimum, maximum, and mode were recorded.

\subsection{Statistical analysis and modeling}

The MLR was developed with R Statistical Software (R Core Team, 2014) using a linear mixed model. A total of 19 potential explanatory variables were identified: digital image data (pixel mean values, time, day of year, and year), weather (air temperature, vapor pressure), field-measured 
snow characteristics (snow depth, snow density, snow-water equivalent, snow age), manure (application timing and presence), tillage (conventional or no-tillage), sky condition (sunny or overcast), measured incoming solar and longwave radiation in $\mathrm{W} \mathrm{m}^{-2}$, and calculated solar position (zenith angle, declination angle, and azimuth). Inputs for manure, tillage, and sky condition were assigned simple rating systems. For manure application timing, the unmanured control was rated as 1 , the December manure application as 2 , and the January manure application as 3 . Tillage was rated as 1 for conventional tillage and 2 for no-tillage. The 'presence of manure' variable was rated 0 if no manure was visible in the image and 1 if manure was in the image. Similarly, sky condition was rated as 0 for overcast and 1 for clear.

While digital imagery and surface conditions were captured across all plots on each of the 40 dates, only data from the plots that also had direct measurements of albedo with a net radiometer were used to build the MLR (i.e. one plot per date during the freezing season of 2015-2016 and three plots per date during the freezing season of 2016-2017). This procedure yielded a total of 110 ground-truthed data points. The assumptions of the MLR were tested with the following: 1) linearity and transformations were tested with a scatterplot matrix of each explanatory variable and albedo, 2) equal variance was tested with residual versus fitted plots, 3) normality was tested with quantile-quantile (QQ) plots, 4) leverage through Cook's Distance and the Bonferroni Outlier Test $(\alpha=0.05)$ were used to check for outliers, and 5) variance-inflation factors (VIF) were used to test for multicollinearity. The MLR was cross-validated by partitioning the data with an $80 / 20$ split. Data points were randomly assigned to a Training Set, with which the explanatory variables were selected through Subset Model Selection, and estimates of coefficients were calculated. The remaining data points were reserved as the Test Set, which was used to evaluate the predictive error of the model by calculating the root mean squared error (RMSE). A final model was 
determined using the Bayesian Information Criterion (BIC), adjusted $\mathrm{R}^{2}\left(\mathrm{R}_{\text {adjusted }}{ }^{2}\right)$, and RMSE selection criteria.

The final MLR model was used to calculate the albedo of all of the plots across the 40 dates in 2015-2016 and 2016-2017. To quantify the effect of the manure on resultant solar, longwave, and net radiation, the following calculations were made:

$$
R_{N E T}=S_{N E T}+L W_{N E T}
$$

where $\mathrm{R}_{\mathrm{NET}}$ is net radiation, $\mathrm{S}_{\mathrm{NET}}$ is net solar radiation, and $\mathrm{LW}_{\mathrm{NET}}$ is net longwave radiation, units are in $\mathrm{W} \mathrm{m}^{-2}$, and

$$
\begin{aligned}
& S_{N E T}=S_{\downarrow}-S_{\uparrow}=(1-\alpha) S_{\downarrow} \\
& S_{\uparrow}=\alpha S_{\downarrow} \\
& L W_{N E T}=L W_{\downarrow}-L W_{\uparrow} \\
& L W_{\uparrow}=\varepsilon \sigma T^{4}
\end{aligned}
$$

where $S_{\downarrow}$ is incoming solar radiation that was directly measured by the net radiometers and $S_{\uparrow}$ is reflected solar radiation that was calculated from albedo, $\alpha . \mathrm{LW}_{\downarrow}$ is the incoming longwave radiation that was directly measured by the net radiometers. $\mathrm{LW}_{\uparrow}$ is outgoing longwave radiation, which was calculated by the Stefan-Boltzmann constant, $\sigma=5.67 \mathrm{E}-8 \mathrm{~W} \mathrm{~m}^{-2} \mathrm{~K}^{-4}$, and $\mathrm{T}$, the surface temperature of each treatment in Kelvin measured by the infrared radiometers. A mean of 0.98 was used for the emissivity, $\varepsilon$, of snowpack, as measured by the net radiometers in this study, which is comparable to other established values (Hewison and English, 1999; Wan, 2008; Warren, 1982). Daily averages of 24-hour incoming solar and longwave radiation were calculated and albedo estimates were used to calculate the average daily absorbed solar radiation for each plot, which allowed for averages and standard error to be calculated across manure and tillage treatments. The data related to longwave radiation, including net radiation, were restricted to one 
daily value per treatment because only one replication was instrumented with infrared radiometers for the ground surface temperature measurement.

\section{Results and Discussion}

\subsection{Monitoring conditions}

Average air temperature and total precipitation were greater during the winters of 2015-2016 and 2016-2017 than the 30 year normal (1981-2010; NOAA, 2017), and there were fewer days of frozen ground compared to 10-year averages (University of Wisconsin, 2010) (Table 1). Six thaw events occurred during the 74 days of frozen ground in the 2015-2016 monitoring year and nine thaw events occurred during the 94 days of frozen ground in the second monitoring year (Figure 1).

The 10 December 2015 manure application occurred on unfrozen, bare soil, as the soil froze 41 days later than average and snow did not accumulate until 31 December 2015 (Figures 1 and 2). On 26 January 2016, manure was applied on top of snow that was $15.6 \mathrm{~cm}$ deep $(\mathrm{SE}=0.6)$ with a SWE of $24 \mathrm{~mm}(\mathrm{SE}=1)$ and underlying frozen soil. The 9 December 2016, application was on top of snow with an average depth of $6.1 \mathrm{~cm}(\mathrm{SE}=0.3), \mathrm{SWE}$ of $10 \mathrm{~mm}(\mathrm{SE}=1)$, and underlying frozen soil. The 27 January 2017, application was on top of snow with an average depth of $19.6 \mathrm{~cm}(\mathrm{SE}=0.4), \mathrm{SWE}$ of $31 \mathrm{~mm}(\mathrm{SE}=1)$, and underlying frozen soil. By $22 \mathrm{Feb} .2017$, the soil thawed after the maximum air temperature was over 20 degrees greater than the normal, but refroze from 3-21 March 2017.

\subsection{MLR Results}

The assumptions of the MLR were met for all data points and eight explanatory variables were significant to the MLR: day of year, solar declination angle, manure application timing, presence of manure, mean pixel value of the digital image, snow depth, presence of overcast versus clear 
sky, and air temperature (Table 2). Each of these eight inputs represent accessible data that are conducive to rapid measurement in applied, plot-scale research. A strong relationship was obtained between observed versus predicted albedo estimates, $\mathrm{R}_{\text {adjusted }}{ }^{2}=0.87$ (Figure 3 ).

\subsection{Tillage and liquid manure application impacts on albedo and snowpack}

The albedo ranged from 0.08 for thawing soil without snowpack to 0.95 for fresh snow, and liquid manure application resulted in a patchy, discontinuous layer of manure that infiltrated the underlying snowpack. As the 26 January 2016 application took place prior to the MLR development, only a net radiometer recorded the change in albedo from 0.95 of the freshly fallen snow from the night before to 0.33 after manure application on no-tillage soils. Between 27-29 January, the albedo of unmanured snowpack remained above 0.89 , whereas the manured plot remained below 0.4 . Snowmelt began on 30 January and by 1 February 2016, the albedo of the manured plot decreased to 0.12 , while the unmanured snowpack decreased to 0.46 . The MLR method was added 08 February, after there was a clear need to capture abrupt changes in albedo with additional small-scale snowfall events and a second thaw event between 02-07 February. Despite there having already been two (incomplete) melt events post-manure application, the manure exhibited a legacy effect on albedo through 15 February 2016 because of low and intermittent snowfall. A total of $4 \mathrm{~mm}$ (SWE) of new snow fell between 27 January - 08 February 2016, after which no snowfall occurred until late March (Figure 1 and 2). Increases in albedo from new snow were temporary in the January-manured plots, as the shallowly-buried manure layer remained well within the penetration depth of solar radiation, which is estimated to be $10-16 \mathrm{~mm}$ SWE, or a $10 \mathrm{~cm}$ snow depth (Baker et al., 1991; O’Neill and Gray, 1973; Perovich, 2007). By 20 February 2016, the next date of digital imagery, a large-scale snowmelt occurred and all of the 
snowpack melted. After this event, the January-manured treatments were not different from other manure timings.

After developing the MLR in late winter 2015-2016, more temporally detailed measurements were completed for the winter of 2016-2017. On 9 December 2016, the manure application decreased the albedo from $0.71(\mathrm{SE}=0.00)$ to $0.46(\mathrm{SE}=0.04)$ on conventional tillage and 0.69 $(\mathrm{SE}=0.01)$ to $0.39(\mathrm{SE}=0.04)$ on no-tillage. From 10-12 December 2016, $14 \mathrm{~mm}$ SWE fell, bringing the albedo of all the plots between $0.8-0.9$, and no additional differences in albedo were estimated from the December application. Between 24 December 2016 and 10 January 2017, primarily frozen conditions with intermittent rain, snow drift, and a lack of new snowfall caused overall reductions in snow depth and greater variability between tillage treatments (Figures 1 and 2). Snowpack particularly decreased on conventionally tilled soils as the shallowly buried ridges were within the penetration depth of solar radiation and gradually became exposed. During that 18-day period without new snow and $28 \mathrm{~mm}$ of rain, the albedo of conventional tillage decreased to 0.31 , while no-tillage decreased to 0.43 . New snowfall occurred on 11 January 2017 and became more frequent through the end of the month, reducing the differences between tillages.

On 27 January 2017, the manure application decreased the albedo from $0.73(\mathrm{SE}=0.02)$ to $0.45(\mathrm{SE}=0.04)$ on conventional tillage and $0.74(\mathrm{SE}=0.01)$ to 0.48 on no-tillage $(\mathrm{SE}=0.01)$. These decreases are significant and similar to decreases in snow albedo from volcanic ash deposits ( 0.84 to 0.36 ), which were found to accelerate the rate of snowmelt by about $150 \%$ (Young et al., 2014). After new snowfall on 31 January $(\mathrm{SWE}=1.8 \mathrm{~mm})$, all of the treatments had similar albedos. As snow aged and additional precipitation included rain (e.g. $1.6 \mathrm{~mm}$ of rainfall on 5 February), the albedo of the January manure treatment, regardless of tillage, remained lower than that of other application timings and lasted for three weeks. Specifically, the albedo from the 
January applications remained 0.51 to 0.41 lower in conventional tillage and no-tillage, respectively, than plots with no manure or December applications. This may be explained by overall site conditions - more precipitation fell as snow in December 2016, and masked the December manure layer (Figure 2). The thickness and duration of any new snow cover on top of the January manure layer was minimized by more precipitation falling as rain in January and February (Figure 1), as well as the greater intensity of solar irradiance after the winter solstice.

\subsection{Discussion of Liquid Manure Application and Tillage on Radiative Energy and Runoff}

With lasting changes in the estimated albedo, differences in the reflected solar radiation, hence average daily net radiation, became pronounced after the January manure applications across tillage treatments in both winters. During winter 2015-16, reflected solar radiation decreased by an average of $50 \mathrm{~W} \mathrm{~m}^{-2}$ from the January application on no-tillage until 01 February 2016 (as recorded by net radiometers), when a large melt event caused much of the applied manure to runoff. New snowfall and subsequent melts reduced these differences for the remainder of that winter (as captured by the MLR) (Figure 4). At the onset of the January 2017 application, the average daily reflected solar radiation decreased by $36.4(\mathrm{SE}=3.6) \mathrm{W} \mathrm{m}^{-2}$ in conventional tillage and $35.0(\mathrm{SE}=1.3) \mathrm{W} \mathrm{m}^{-2}$ in no-tillage, compared to unmanured controls (Figure 4c). These differences in reflected solar radiation between the January application and control increased during snowmelt events until a maximum average daily difference of $75.8 \mathrm{~W} \mathrm{~m}^{-2}(\mathrm{SE}=6.1)$ was reached on conventional tillage and $96.2(\mathrm{SE}=3.1) \mathrm{W} \mathrm{m}^{-2}$ on no-tillage in mid-February 2017. As a result, SWE decreased up to 9 and $12 \mathrm{~mm} \mathrm{~d}^{-1}\left(2-5 \mathrm{~cm} \mathrm{~d}^{-1}\right.$ as snow depth) faster from January applications compared to December applications and controls in conventional versus no-tillage, respectively (Figure 2). Snowpack disappeared up to three days earlier during thaw events, effectively reducing the length of the events by half. While different in scale, the trends are in 
agreement with those regarding dust deposition on subalpine snowpack: as radiative absorption increased by $35-70 \mathrm{~W} \mathrm{~m}^{-2}$ from dust, $600 \mathrm{~mm}$ of SWE disappeared 51 days earlier than in regions of dust-free snow (Skiles et. al, 2012).

A secondary difference in reflected solar radiation arose from tillage type. During the late December 2016 and mid-February 2017, the average daily reflected solar radiation from conventional tillage was up to $50 \mathrm{~W} \mathrm{~m}^{-2}$ lower than no-tillage (Figure 4). This difference is attributed to the network of ridges and furrows created by the fall chisel plow. Snow tended to be thinner on the ridges, allowing the underlying bare soil surface to influence the snow surface albedo and in turn, cause the thinner snow to regress during melts. Therefore, the presence of the ridges lowered albedo, allowing for greater absorption of solar radiation with conventional tillage. Under no-tillage, snowpack was able to form as a deeper, continuous layer with a greater albedo unless manure was added in late January. The strong contrast in reflected solar radiation between January manure applications and controls was lower in conventional tillage when soil ridges were exposed than in no-tillage.

The average and maximum daily surface temperatures of the plots were not significantly different (Figure 5), thus differences in outgoing longwave radiation were also not significant. The decrease in albedo from solid-bedded manure applications can increase the temperature of the manure layer above freezing (Kongoli \& Bland, 2002). The lack of surface heating from liquid manure, however, may be attributed to the interaction between the manure and snowpack. After liquid manure is applied, the manure does not remain as a discrete layer, but instead infiltrates into the snow with little residue left at the snow surface, creating a mixed snow/manure layer with a lowered albedo. The thermal conductivity of the liquid manure was $0.62-0.70 \mathrm{~W} \mathrm{~m}^{-1} \mathrm{~K}^{-1}$, or 5.5 times greater than that of the solid-bedded manure measured by Kongoli and Bland (2002), due to 
the higher water content and potential sand bedding residuals associated with liquid manure systems. Consequently, as the albedo decreased from manure applications, the absorbed energy was transmitted to the snowpack instead of being confined to the manure.

The net radiation during thaw events indicated the legacy effect of late-January applications of liquid manure on snow albedo, regardless of tillage, and highlights the risk of accelerating snowmelt and increasing potential nutrient loads in runoff. The cumulative net radiation was 5.1 MJ $\mathrm{m}^{-2} \mathrm{~d}^{-1}$ greater from January applications versus controls or December applications across tillages during the 6-8 February 2017 thaw, and $19 \mathrm{MJ} \mathrm{m}^{-2} \mathrm{~d}^{-1}$ greater during $10-14$ February 2017. Cumulative across the season on dates in which albedo was measured, net radiation was 4.5 $\mathrm{MJ} \mathrm{m}^{-2} \mathrm{~d}^{-1}$ greater with December application compared to unmanured control, and $44.0 \mathrm{MJ} \mathrm{m}^{-2}$ $\mathrm{d}^{-1}$ greater with January application compared to the control.

The increases in net radiation and accelerated snowmelt resulted in greater runoff losses from the late-January manure application. While all wintertime manure additions inherently add risk to runoff losses (Vadas et al., 2017), liquid manure applied in late-January intensified surface nutrient transport (Table 3). The earlier onset of runoff and increase to the total runoff volume caused concentrated nutrient loads during key melt events on frozen soils. As a result, surface losses of nitrogen and phosphorus doubled on soils with late-January applications compared to those with early-December. This is attributed to the prolonged increase in net radiation from the late-January application, regardless of new snowfall, that infiltrated underlying snowpack and directly transmitted absorbed solar radiation to melt processes. Changes to the surface energy balance from late applications of liquid manure add further concern to this sensitive time of year by coinciding with environmental conditions that already promote runoff on frozen soils: slowed infiltration from greater pore ice development (Niu and Yang, 2006), increasing intensity of solar irradiance after 
the winter solstice, increasing air temperature, and greater frequency of rain. This contrasts the mulching effect from solid-bedded manure that allows more time for infiltration by slowing snowmelt, thereby reducing some nutrient loss from applications (Kongoli and Bland, 2002). Therefore, wintertime applications of liquid manure, and especially those later in the freezing season, add risk to nutrient management by accelerating snowmelt, which generates additional environmental concerns for runoff as producers move from solid to liquid manure forms.

\section{Conclusion}

This study monitored the influence of liquid dairy manure application timing (early versus later in the freezing season) and tillage (conventional fall tillage with a chisel plow versus no-tillage) on the resultant radiative energy fluxes on soils with snowpack. First, a multiple linear regression model was developed with digital imagery and readily-obtained site characteristics to repeatedly estimate plot-scale albedo over time after dynamic snow behavior and field operations. With these estimates of albedo, radiative fluxes were calculated for each management treatment. Liquid manure applied on top of snow infiltrated the underlying snowpack, creating a generally homogenized snow-manure layer with a lower albedo. While early-winter applications of manure did not alter radiative energy fluxes through albedo longer than the day of the application, lateJanuary applications produced a lasting effect, as mixed precipitation and more intense irradiance after the solstice reduced masking of the manure layer. The surface roughness from conventional tillage reduced albedo, but the effect of tillage on radiative fluxes was secondary to manure application timing. Late applications of liquid manure ultimately accelerated snowmelt that increased runoff and doubled nutrient loads, posing a challenge to nutrient retention on frozen ground. 


\section{Acknowledgements}

This work was funded by the USDA National Institute of Food and Agriculture, Agriculture and Food Research Initiative (Project \#3958). Additional research assistantship support for M.N.S. was provided by the University of Wisconsin-Madison Champ B. Tanner Agricultural Physics Award and other funding was provided by the NCR SARE Graduate Student Grant (Project \#GNC14-197) and Decagon Devices GA Harris Fellowship (2014). We thank Laura W. Good for technical, Chris Kucharik for biophysical, and Nick Keuler for statistical feedback. We also appreciate Mike Bertram and staff at the Arlington Agricultural Research Station; Nick Bero, Joe Bevington, Andy Larson, Jim Richmond, Peter Wakeman, and Zach Zopp for their field support; and the reviewers for their helpful suggestions. The authors state no conflicts of interest and data are available upon request.

\section{References}

Baker, D., Skaggs, R., and Ruschy, D. (1991). Snow Depth Required to Mask the Underlying Surface. J. Appl. Meteorol (1988-2005), 30(3), 387-392. https://doi.org/10.1175/15200450(1991)030<0387:SDRTMT>2.0.CO;2

Bonilla, C.A., Kroll, D.G., Norman, J.M., Yoder, D.C., Molling, C.C., Miller, P.S., Panuska, J.C., Topel, J.B., Wakeman, P.L., and Karthikeyan, K.G. (2006). Instrumentation for measuring runoff, sediment, and chemical losses from agricultural fields. J. Environ. Qual., 35(1), 216-23. https://doi.org/10.2134/jeq2005.0130

Carpenter, S.R., Caraco, N.F., Correll, D.L., Howarth, R.W., Sharpely, A.N., \& Smith, V.H. (1998). Nonpoint pollution of surface waters with phosphorus and nitrogen. Ecol. Appl., 8(3), 559-568. https://doi.org/10.1890/1051-0761(1998)008[0559:NPOSWW]2.0.CO;2 
Converse, J.C., Bubenzer, G.D., \& Paulson, W.H. (1976). Nutrient Losses in Surface Runoff from Winter Spread Manure. Trans. ASAE., 19, 517-519. https://doi.org/10.13031/2013.36061

Corripio, J.G. (2004). Snow surface albedo estimation using terrestrial photography. Int. J. Remote Sensing., 25(24), 5705-5729. https://doi.org/10.1080/01431160410001709002

Good, L.W., Vadas, P.A., Panuska, J.C., Bonilla, C.A., \& Jokela, W.E. (2012). Testing the Wisconsin Phosphorus Index with Year-Round, Field-Scale Runoff Monitoring. J. Environ. Qual., 41, 1730-1740. https://doi.org/10.2134/jeq2012.0001

Gray, D.M. and Landine, P.G. (1987). Albedo model for shallow prairie snow covers. Can. J. Earth Sci., 24(9), 1760-1768. https://doi.org/10.1139/e87-168

Hensler, R.F., Olson, R.J., Witzel, S.A., Attoe, O.J., Paulson, W.H., \& Johannes, R.F. (1970). Effect of method of manure handling on crop yields, nutrient recovery, and runoff losses. $T$. ASAE., 13(6), 726-731. https://doi.org/10.13031/2013.38706

Hewison, T.J. and English, S.J. (1999). Airborne retrievals of snow and ice surface emissivity at millimeter wavelengths. IEEE T. Geosci. Remote., 37(4), 1871-1879. https://doi.org/10.1109/36.774700

Idso, S.B., Jackson, R.D., Reginato, R.J., Kimball, B.A., \& Nakayama, F.S. (1975). The dependence of bare soil albedo on soil water content. J. App. Met., 14, 109-113. https://doi.org/10.1175/1520-0450(1975)014<0109:TDOBSA>2.0.CO;2

Klausner, S.D., Zwerman, P.J., \& Ellis, D.F. (1976). Nitrogen and Phosphorus Losses from Winter Disposal of Dairy Manure. J. Environ. Qual., 5, 47-49. https://doi.org/10.2134/jeq1976.00472425000500010010x 
Komiskey, M.J., Stuntebeck, T.D., Frame, D.R., \& Madison, F.W. (2011). Nutrients and sediment in frozen-ground runoff from no-till fields receiving liquid-dairy and solid-beef manures. J. Soil Water Conserv., 66(5), 303-312. https://doi.org/10.2489/jswc.66.5.303

Kongoli, C.E., \& Bland, W.L. (2002). Influence of manure application on surface energy and snow cover: Field experiments. J. Environ. Qual., 31, 1166-1173. https://doi.org/10.2134/jeq2002.1174

Lobell, D.B., \& Asner, G.P. (2002). Moisture effects on soil reflectance. Soil Sci. Soc. Am. J., 66(3), 722-727. https://doi.org/10.2136/sssaj2002.7220

MacKay, J.R. (1973). A frost tube for the determination of freezing in the active layer above permafrost. Can. Geotech. J., 10, 392-396. https://doi.org/10.1139/t73-033

Murphy, J. and Riley, J.P. (1962). A modified single solution method for the determination of phosphate in natural waters. Anal. Chim. Acta., 27, 31-36. https://doi.org/10.1016/S0003$2670(00) 88444-5$

National Oceanic and Atmospheric Administration (NOAA). (2017). NOAA National Centers for Environmental Information Data Tools: 1981-2010 Normals. Retrieved from: https://www.ncdc.noaa.gov/data-access/land-based-station-data/land-based-datasets/climatenormals/1981-2010-normals-data. Accessed: 13 October 2017.

Niu, G.-Y. and Yang, Z.-L. (2006). Effects of frozen soil on snowmelt runoff and soil water storage at a continental scale. J. Hydrometeorol., 7, 937-952. https://doi.org/10.1175/JHM538.1

O’Neill, A.D.J. and Gray, D.M. (1973). Solar radiation penetration through snow. IAHS AISH Publ., 107, 227-241. International Symposia on the Role of Snow and Ice in Hydrology, 1, available at: http://iahs.info/redbooks/a107/107019.pdf, 227-241. 
Owens, L.B., Bonta, J.V., Shipitalo, M.J., \& Rogers, S. (2011). Effects of winter manure application in Ohio on the quality of surface runoff. J. Environ. Qual., 40, 153-165. https://doi.org/10.2134/jeq2010.0216

Perovich, D.K. (2007). Light reflection and transmission by a temperate snow cover. J. Glaciol., 53(181), 201-209. https://doi.org/10.3189/172756507782202919

Peters, J., Combs, S.M., Hoskins, B., Jarman, J., Kovar, J.L., Watson, M.E., Wolf, A.M., and Wolf, N. (2003). Recommended Methods of Manure Analysis. Cooperative Extension Publishing University of Wisconsin-Extension Publication A3769. http://learningstore.uwex.edu/assets/pdfs/A3769.pdf. Accessed: 16 April 2018.

Rickard, W., \& Brown, J. (1972). The performance of a frost-tube for the determination of soil freezing and thawing depths. Soil Sci., 113(2), 149-154.

Schindelin, J., Arganda-Carreras, I., Frise, E., Kaynig, V., Longair, M., Pietzsch, T., Preibisch, S., Rueden, C., Saalfeld, S., Schmid, B., Tinevez, J.Y., White, D.J., Hartenstein, V., Eliceiri, K., Tomancak, P., Cardona, A. (2012). Fiji: an open-source platform for biological-image analysis. Nat. Methods, 9, 676-82. https://doi.org/10.1038/nmeth.2019

SEAL Analytical Inc. (2017). Discrete Analyzer EPA Methods. Retrieved from: sealanalytical.com.tempdomain.com/Methods/DiscreteMethods/DiscreteAnalyzerEPAMetho ds/tabid/76/language/en-US/Default.aspx. Accessed: 22 Nov. 2017.

Skiles, S.M., Painter, T.H., Deems, J.S., Bryant, A.C., and Landry, C.C. (2012). Dust radiative forcing in snow of the Upper Colorado Basin: 2. Interannual variability in radiative forcing and snowmelt rate. Water Resour. Res., 48, W07522.

https://doi.org/10.1029/2012WR011986 
Srinivasan, M.S., Bryant, R.B., Callahan, M.P., \& Weld, J.L. (2006). Manure management and nutrient loss under winter conditions: A literature review. J. Soil Water Conserv., 61, 200209. https://doi.org/10.2489/jswc.68.3.185

Stuntebeck, T.D., Komiskey, M.J., Peppler, M.C., Owens, D.W., \& Frame, D.R. (2011). Precipitation-runoff relations and water quality characteristics at edge-of-field stations, Discovery Farms and Pioneer Farm, Wisconsin, 2003-8. SIR; 2011-5008: U.S.G.S. Scientific Investigations Report. Retrieved from: https://pubs.usgs.gov/sir/2011/5008/. Accessed 15 August 2018.

University of Wisconsin. (2010). UW Extension Ag Weather: NWS Co-Op Observer Reports. Retrieved from: http://agwx.soils.wisc.edu/uwex_agwx/weather/hyd. Accessed: 13 October 2017.

U.S. Army Corps of Engineers. (2015). Measuring plains snow water equivalent and depth: Missouri Basin Water Management Division and Omaha District Method. Northwestern Division, Missouri River Basin Water Management Division. Retrieved from: http://www.nwd-mr.usace.army.mil/rcc/. Accessed: 23 February 2018.

USDA-NASS. (2010). Overview of the United States Dairy Industry. Agricultural Statistics Board. Retrieved from: http://usda.mannlib.cornell.edu/usda/current/USDairyIndus/USDairyIndus-09-22-2010.pdf. Accessed: 13 October 2017.

USDA NRCS (Natural Resources Conservation Service). (2015). Conservation Practice Standard 590. Wisconsin Field Office Technical Guide. Retrieved from: https://efotg.sc.egov.usda.gov/references/public/WI/590.pdf. Accessed: 13 October 2017. 
USEPA. (2015). US EPA Watershed Assessment, Tracking, and Environmental Results.

Retrieved from: http://ofmpub.epa.gov/waters10/attains_nation_cy.control. Accessed: 13 October 2017.

Vadas, P.A., Good, L.W., Jokela, W.E., Karthikeyan, K.G., Arriaga, F.A., Stock, M.N. (2017). Quantifying the impact of seasonal and short-term manure application decisions on phosphorus loss in surface runoff. J. Environ. Qual., 46(6), 1395-1402. https://doi.org/10.2134/jeq2016.06.0220

Vadas, P.A. and Powell, J.M. (2013). Monitoring nutrient loss in runoff from dairy cattle lots. Agr. Ecosyst. Environ., 181, 127-133. https://doi.org/10.1016/j.agee.2013.09.025.

Wan, Z. (2008). New refinements and validation of the MODIS Land-Surface Temperature/Emissivity products. Proc. Spie., 112(1), 59-74. https://doi.org/10.1016/j.rse.2006.06.026

Warren, S.G. (1982). Optical properties of snow. Rev. Geophys. Space GE., 20(1), 67-89. https://doi.org/10.1029/RG020i001p00067

Warren, S.G. and Wiscombe, W.J. (1985). Dirty snow after nuclear war. Nature, 313, 467-470. https://doi.org/10.1038/313467a0

Wendt, K. (2000). Determination of nitrate/nitrite in surface and wastewaters by flow injection analysis (low flow method). Lachat Instruments, QuikChem Methods 12-107-04-1-B. Retrieved from: https://www.uvm.edu/bwrl/lab_docs/protocols/Nitrate_water_lachat.pdf. Accessed: 15 August 2018.

Wiscombe, W.J., \& Warren, S.G. (1980). A model for the spectral albedo of snow I: Pure Snow. J. Atm. Sci., 37, 2712-2733. https://doi.org/10.1175/1520-

0469(1980)037<2712:AMFTSA>2.0.CO;2 
Young, C.L., Sokolik, I.N., Flanner, M.G., and Dufek, J. (2014). Surface radiative impacts of ash deposits from the 2009 eruption of Redoubt volcano. J. Geophys. Res., 119, 11387-11397. https://doi.org/10.1002/2014JD021949

Young, R.A., \& Mutchler, C.K. (1976). Pollution potential of manure spread on frozen ground. J. Environ. Qual., 5, 174-179. https://doi.org/10.2134/jeq1976.00472425000500020013x 


\section{Figure captions}

Figure 1. Weather conditions during a) 2015-16 and b) 2016-17, with average hourly air temperature in ${ }^{\circ} \mathrm{C}$ (thin black line), total daily precipitation in $\mathrm{mm}$ as rainfall (blue bar) or the liquid equivalent of snowfall (gray bar), the presence of frozen soil (thick black line on x-axis), and thaw events during the freezing seasons (salmon bar). Vertical arrows designate the manure application dates.

Figure 2. Average snow depth ( \pm standard error) in cm during a) 2015-2016 and b) 2016-2017, by tillage and manure application timing treatments: conventional tillage control, CTC (white circle); conventional tillage December application, CTD (white square); conventional tillage January application, CTJ (white triangle); no-tillage control, NTC (black circle); no-tillage December application, NTD, (black square); and no-tillage January application, NTJ, (black triangle). Vertical arrows designate the manure application dates.

Figure 3. Observed versus predicted albedo from the MLR model, by Training Set $(\mathrm{n}=88$, black circle) and Test Set $(n=22$, white circle $) . R^{2}=0.87$ for the full dataset across 40 days in 20152016 and 2016-2017.

Figure 4. Average reflected solar radiation, $\mathrm{S}_{\uparrow},( \pm$ standard error $)$ in $\mathrm{W} \mathrm{m}^{-2}$ during a) late winter 2015-2016, b) 01 December 2016 - 26 January 2017, and c) 26 January to 27 February 2017, by tillage and manure timing treatments: conventional tillage control, CTC (white circle); conventional tillage December application, CTD (white square); conventional tillage January application, CTJ (white triangle); no-tillage control, NTC (black circle); no-tillage December application, NTD, (black square); and no-tillage January application, NTJ, (black triangle). Liquid dairy manure was applied 10 Dec. 2015, 26 Jan. 2016, 09 Dec. 2016, and 27 Jan. 2017, and indicated with a black, vertical line. Vertical arrows designate the manure application dates. 
Figure 5. Average daily surface temperature in ${ }^{\circ} \mathrm{C}$ during a) $2015-2016$ and b) $2016-2017$ by tillage and manure application timing treatments: conventional tillage control, CTC (white circle); conventional tillage December application, CTD (white square); conventional tillage January application, CTJ (white triangle); no-tillage control, NTC (black circle); no-tillage December application, NTD, (black square); and no-tillage January application, NTJ, (black triangle). Vertical arrows designate the manure application dates.

Figure 6. Differences in average net radiation (RNET) between manure application timings and unmanured controls across tillage treatments during 2015-2016 (a) and 2016-2017 (b). Differences include December manure applications minus unmanured controls (white square) and January applications minus unmanured controls (black triangle). Vertical arrows designate the manure application dates. 
Table 1. Air Temperature Expressed as Monthly Averages (Ave), Minimums (Min), and Maximums (Max); Total Monthly Precipitation; and Soil Frost Dates during the 2015-2016 and 2016-2017 Seasons, Compared to Historic Weather Trends

\begin{tabular}{|c|c|c|c|c|c|c|c|c|}
\hline \multirow[t]{3}{*}{ Year } & \multirow[t]{3}{*}{ Month } & \multirow{2}{*}{\multicolumn{3}{|c|}{$\frac{\text { Air Temperature }}{\left[{ }^{\circ} \mathrm{C}\right]}$}} & \multirow{3}{*}{$\frac{\text { Precipitation }}{[\mathrm{mm}]}$} & \multirow{2}{*}{\multicolumn{3}{|c|}{$\underline{\text { Soil frost dates }}$}} \\
\hline & & & & & & & & \\
\hline & & Ave & Min & Max & & Freeze & Thaw & Days frozen \\
\hline \multirow[t]{4}{*}{$2015-16$} & December & 1.0 & -12.0 & 14.7 & 83 & $30 \mathrm{Dec}$ & $12 \mathrm{Mar}$ & 74 \\
\hline & January & -7.1 & -24.0 & 4.1 & 24 & & & \\
\hline & February & -3.5 & -21.1 & 13.3 & 14 & & & \\
\hline & March & 4.1 & -15.2 & 20.0 & 104 & & & \\
\hline \multirow[t]{4}{*}{ 2016-17 } & December & -5.8 & -25.2 & 5.1 & 65 & $7 \mathrm{Dec}$ & $23 \mathrm{Feb}$ & 94 \\
\hline & January & -5.3 & -21.6 & 5.8 & 83 & 3 Mar & $20 \mathrm{Mar}$ & \\
\hline & February & -0.3 & -16.2 & 19.8 & 64 & & & \\
\hline & March & 0.4 & -16.3 & 16.3 & 52 & & & \\
\hline \multirow{4}{*}{$\begin{array}{l}\text { Historic } \\
\text { weather }\end{array}$} & December & -6.4 & -11.7 & -1.3 & 37 & 19 Nov (2) & $22 \operatorname{Mar}(4)$ & $118(6)$ \\
\hline & January & -9.0 & -14.6 & -3.4 & 29 & & & \\
\hline & February & -6.5 & -12.1 & -0.9 & 33 & & & \\
\hline & March & -0.3 & -6.4 & 5.7 & 48 & & & \\
\hline
\end{tabular}

Note. Total monthly precipitation (rainfall + snowfall) expressed in liquid equivalents.

${ }^{\mathrm{a}}$ Monthly air temperature and precipitation based on 1981-2010 normals, recorded $16 \mathrm{~km}$ south of the field site at the Dane County Regional Airport in Madison, WI (NOAA, 2017). Average soil frost dates ( \pm one standard deviation) based on 10-year averages (2005-2014), recorded 13 $\mathrm{km}$ west of the field site in Lodi, WI (University of Wisconsin, 2010). 
Table 2. Summary Statistics of the Multiple Linear Regression

\begin{tabular}{lllll}
\hline Explanatory variable & Estimate & Standard Error & $\mathbf{t}$ & $\operatorname{Pr}(>|\mathbf{t}|)$ \\
\hline Intercept & 0.0182 & 0.0810 & 0.225 & 0.8 \\
Day & 0.000378 & 0.0000820 & 4.58 & $<0.001$ \\
Declination & -0.00452 & 0.00180 & 2.52 & 0.01 \\
ManureApp & -0.0430 & 0.0163 & 2.63 & 0.01 \\
ManurePresent & -0.114 & 0.0250 & -4.54 & $<0.001$ \\
PixelMean & 0.00300 & 0.000501 & 5.99 & $<0.001$ \\
SnowDepth & 0.00114 & 0.000202 & 5.62 & $<0.001$ \\
Sky & -0.0745 & 0.02125 & -3.51 & 0.0008 \\
AirTemperature & -0.00895 & 0.00235 & -3.81 & 0.0003 \\
\hline Residual standard error & $0.0867(d f=79)$ & & \\
F-statistic & $74.7(d f=8,79), p<0.001$ & & \\
\hline $\mathrm{R}^{2}$ & 0.883 & & & \\
$\mathrm{R}_{\mathrm{adj}}{ }^{2}$ & 0.871 & & & \\
BIC & -140 & & & \\
\hline
\end{tabular}


Table 3. Cumulative runoff and nutrient loads by manure treatment on frozen soils across

Winters 2015-17

\begin{tabular}{lcccc}
\hline $\begin{array}{l}\text { Manure Application } \\
\text { Timing }\end{array}$ & $\begin{array}{c}\text { Runoff } \\
{[\mathbf{m m}]}\end{array}$ & $\begin{array}{c}\mathbf{T N}^{\mathbf{a}} \\
----\end{array}$ & $\begin{array}{c}\mathbf{T K P}^{\mathbf{b}} \\
{\left[\mathbf{k g ~ h a}^{-1}\right]}\end{array}$ & $\begin{array}{c}\mathbf{D R P}^{\mathbf{c}} \\
----\end{array}$ \\
\hline Unmanured control & 51 & 2.0 & 0.2 & 0.1 \\
December & 56 & 3.7 & 1.1 & 0.9 \\
January & 59 & 9.4 & 2.1 & 1.4 \\
\hline
\end{tabular}

aTotal nitrogen (TN), btotal Kjeldahl phosphorus (TKP), and ${ }^{c}$ dissolved reactive phosphorus (DRP). 

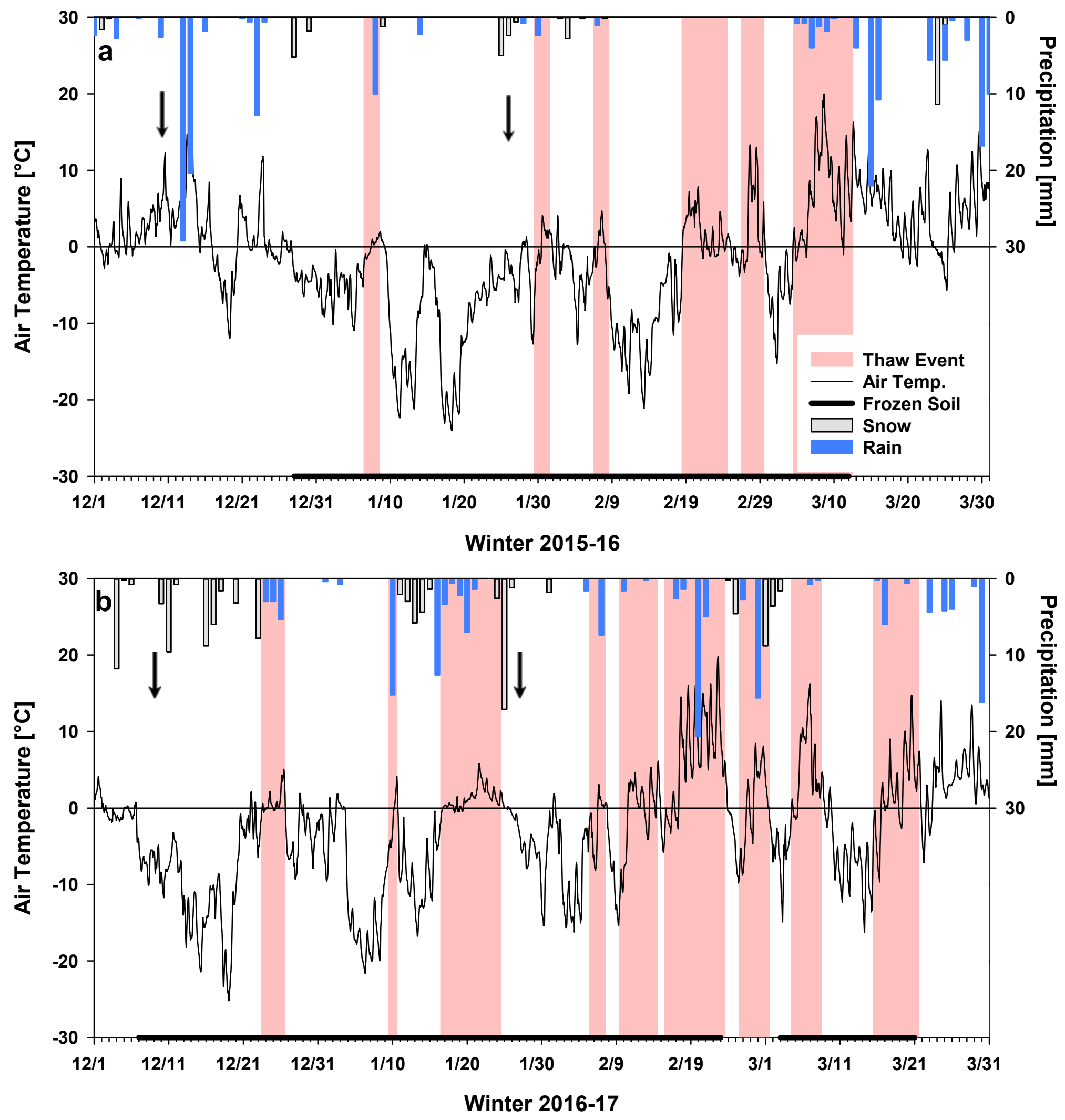

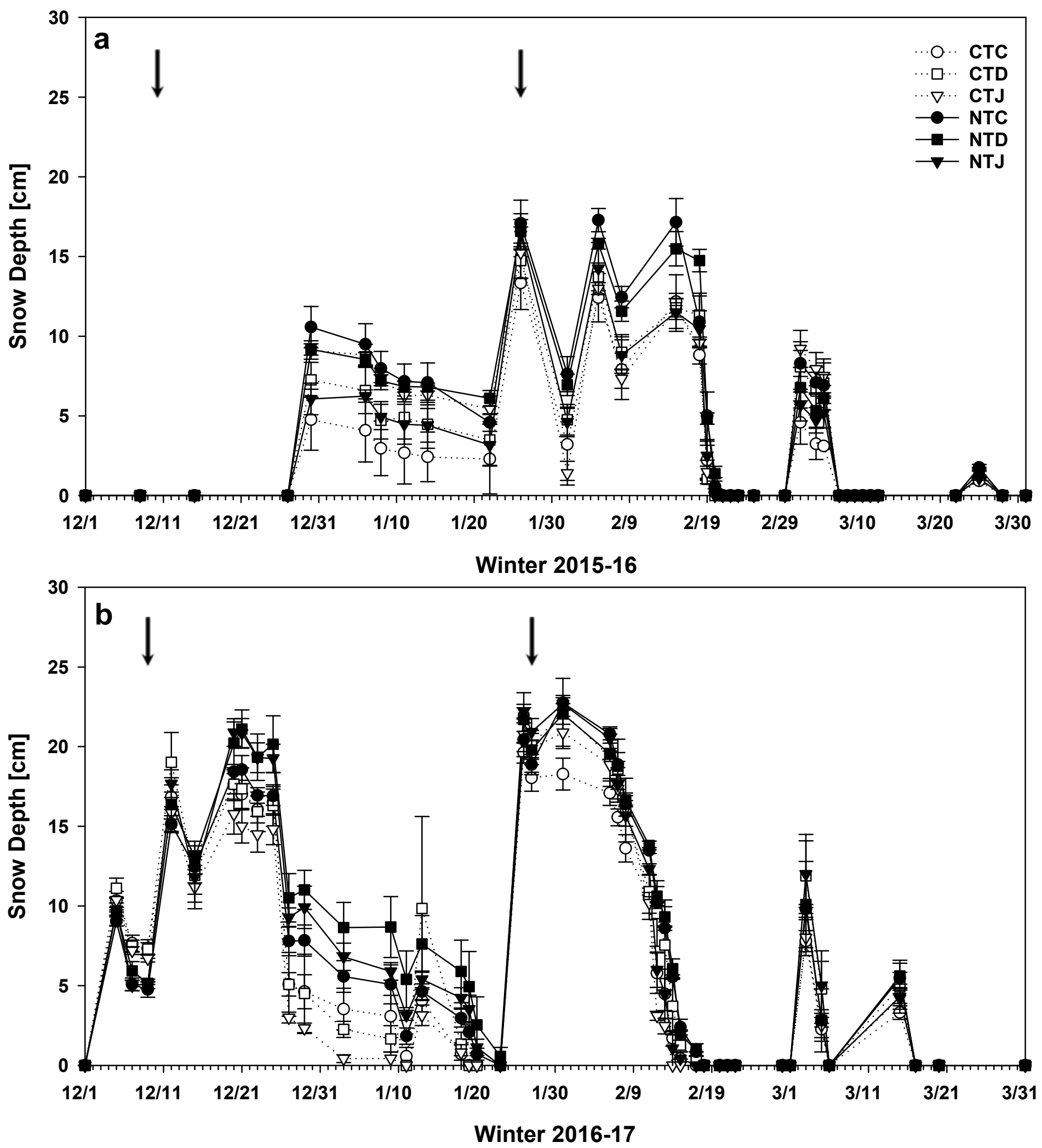


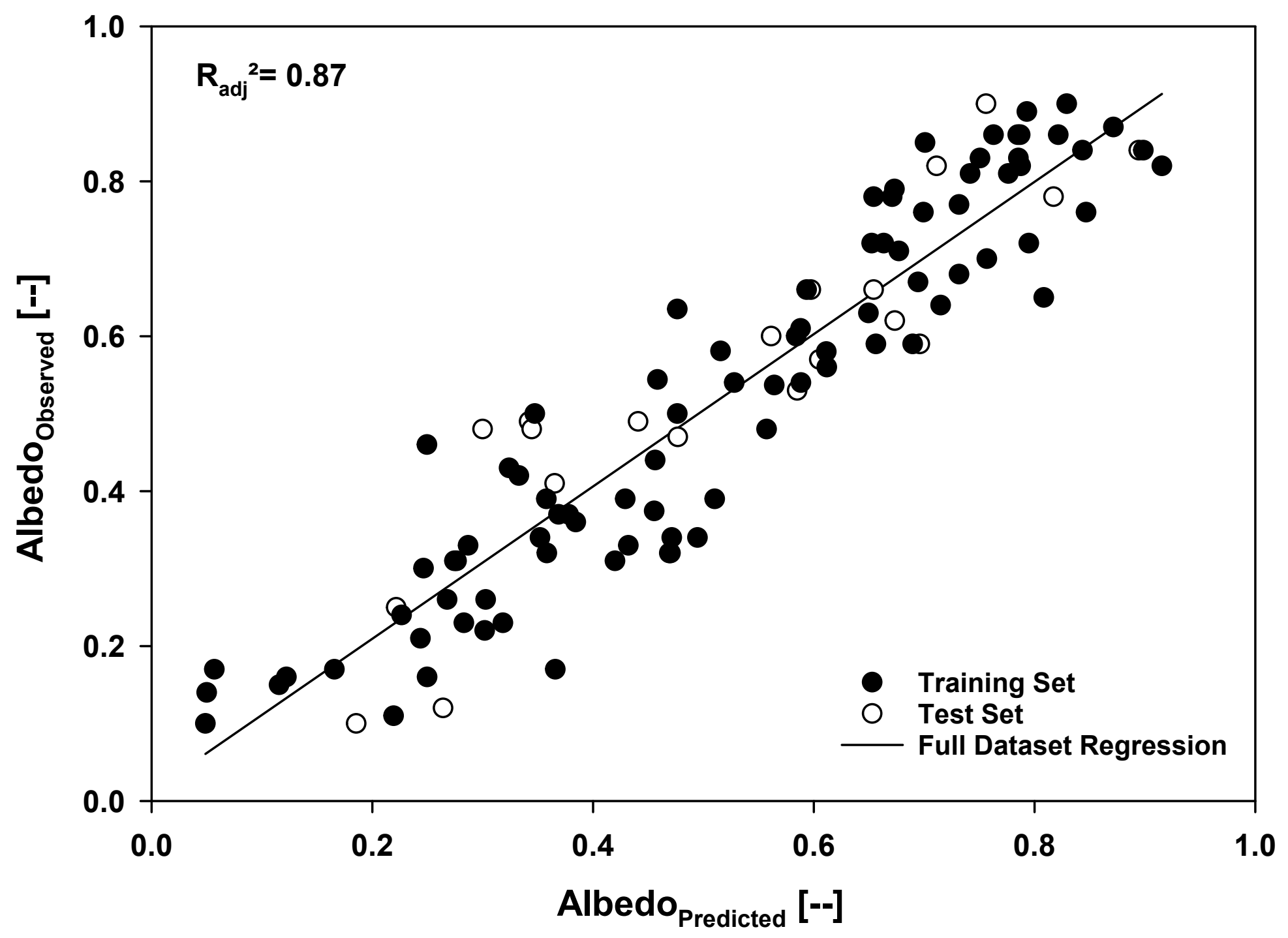



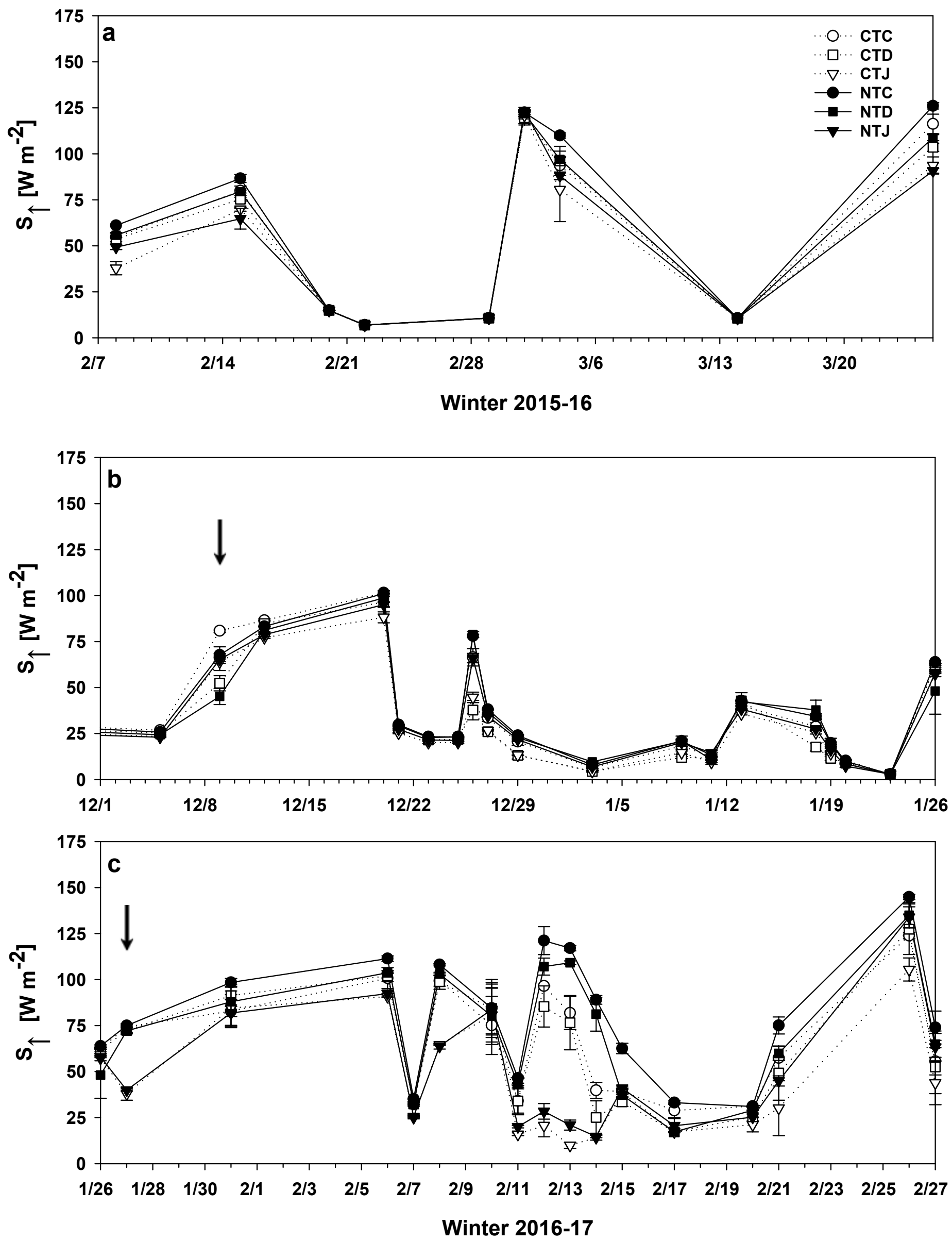


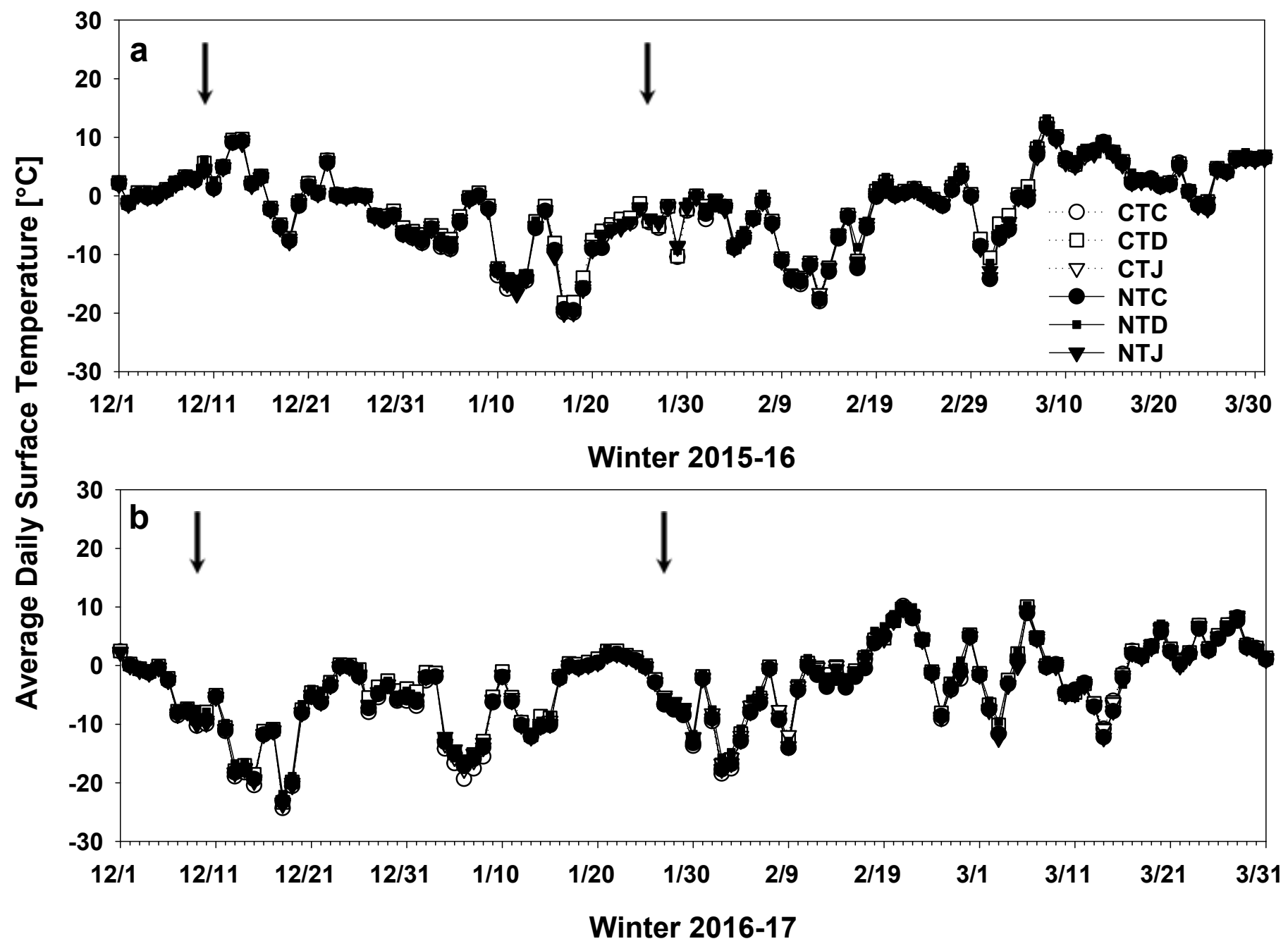



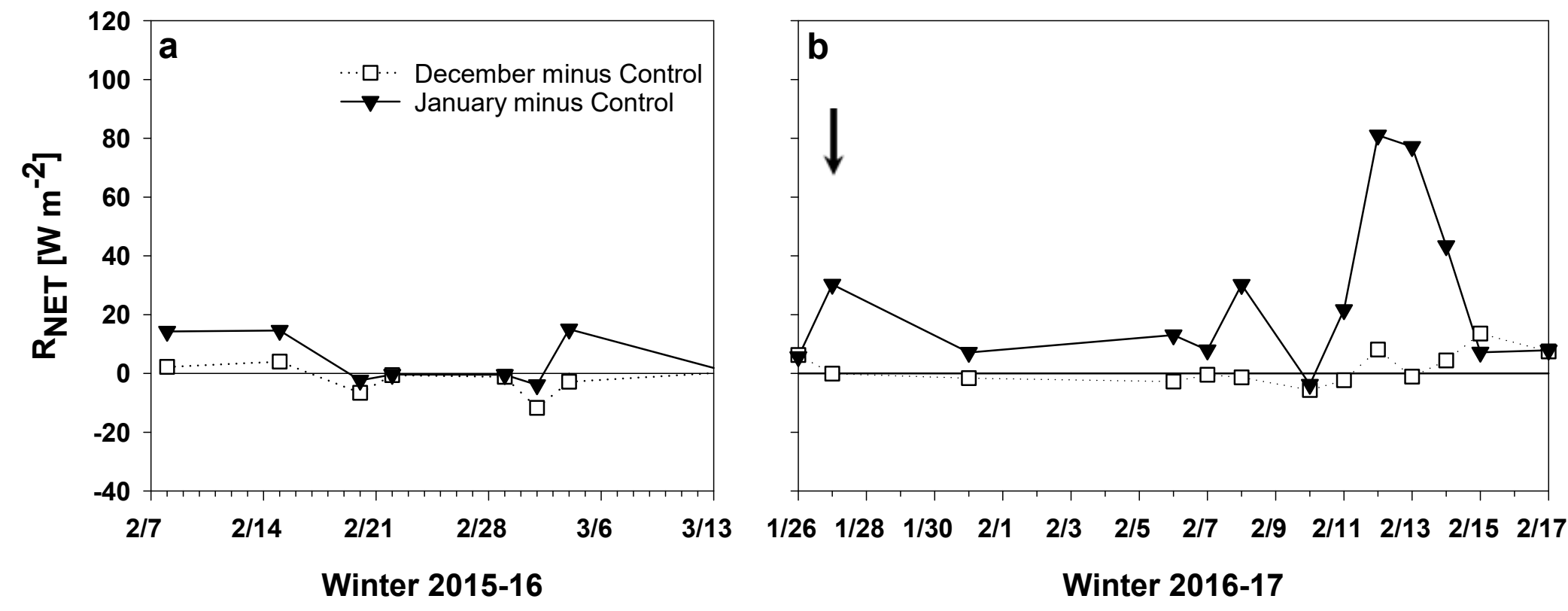